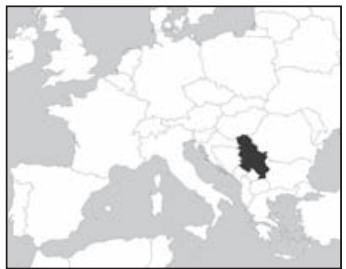

Zlata Vuksanović-Macura is an architect and urban planner. Since 1998, her professional work has focused on social housing and Roma housing and settlements in both policy formulation and project implementation. She has been engaged in and has managed numerous projects related to Roma issues within the NGO Society for the Improvement of Local Roma Communities (SILRC), including the Slum Upgrading Deponija project. Since 2005, she has worked as a housing coordinator at the UN-Habitat Settlement and Integration of Refugees programme in Serbia and as task manager for the Upgrading and Inclusion of Roma Settlement Grdicka Kosa in Kraljevo project. She has been a consultant in the formulation of several national policy documents related to Roma and social housing and is currently working on her PhD dissertation at the Faculty of Architecture in Belgrade.

Address: Ravanička 34, 11050 Belgrade, Serbia; e-mail: zlata.vuksanovic@ gmail.com

\footnotetext{
1. Despite the fact that many European countries established a legal framework and undertook initiatives to combat Roma poverty and discrimination, exclusion of the Roma is one of the most serious social challenges
}

\section{The mapping and enumeration of informal Roma settlements in Serbia}

\author{
ZLATA VUKSANOVIĆ-MACURA
}

ABSTRACT This paper describes five examples of mapping and enumerating poor informal Roma settlements in Serbia, implemented in the last decade by non-governmental organizations and Roma associations as a prelude to different upgrading projects. Their contexts, processes and outcomes are discussed and their common patterns and approaches are summarized. The characteristics and types of Roma settlements are described within the framework of the Roma's poverty and social exclusion and the lack of adequate responses by national and local authorities to the difficult housing situation in Roma settlements. This paper considers ways of overcoming the gap between the need for reliable mapping and enumeration data and the actual situation, where informal Roma settlements are neither put on official maps in Serbia nor included in formal records, unlike other city areas.

KEYWORDS informal settlements / mapping / NGO responses / participatory enumeration / Roma settlements / Serbia / urban poverty

\section{INTRODUCTION}

Roma settlements are a traditional part of the towns and cities in Serbia. Compared to those in other countries in southeastern Europe, Serbia's Roma settlements are small in size and population and most have very poor living conditions - a result of the historical social exclusion, prejudice and intolerance that most of the estimated 10-12 million Roma in Europe face in their daily lives. ${ }^{(1)}$

Starting in 2002, Serbia adopted several laws and other measures to improve Roma living conditions, ${ }^{(2)}$ and participated in launching the international Decade of Roma Inclusion initiative 2005-2015, which specified goals in education, employment, health and housing.(3) The implementation of these policies and measures faces serious difficulties. In the field of housing, this is due to a poor understanding of the problems of Roma settlements, weak political incentive and official responsibility, a lack of data and maps, outdated laws and a lack of resources. ${ }^{(4)}$

Initiatives to improve the living conditions in informal Roma settlements, including enumeration and mapping for upgrading, have been launched primarily by non-governmental organizations (NGOs) and Roma associations (RAs) along with the Roma community, with the aim of establishing cooperation with local authorities and gaining the financial support of international organizations. This paper analyzes five examples of mapping and enumerating informal Roma settlements in Serbia, implemented by NGOs together with RAs or settlement committees (SCs). 


\section{ROMA SETTLEMENTS IN SERBIA}

The term "Roma settlement" refers here to a larger or smaller administratively non-autonomous spatial unit inhabited primarily by Roma and surrounded by territory inhabited by the general population. ${ }^{(5)}$ Other terms used in Serbia, depending on the topic of discussion and the quality of the settlement, include "slum"(6) and "enclave", along with "Gypsy mahalla", "Gypsy settlement" or the pejorative "cardboard city".

\section{a. Historical background}

The Roma arrived in what is present-day Serbia in the fifteenth and sixteenth centuries during the Ottoman conquest of the Balkans. They settled primarily in mahallas, residential parts of towns organized along religious and ethnic lines (there are also Jewish and Greek mahallas), although some had a nomadic lifestyle (čergari). In the mid-nineteenth century, with the gradual liberation from Ottoman rule, both nomadic Roma and others who wanted to become citizens of Serbia were given land on which to settle permanently. ${ }^{(7)}$ Mahallas disappeared during the modernization process at the end of the nineteenth century, with only the Roma mahallas remaining to the present day. As of the mid-twentieth century, in changed social and political conditions, the Roma also mixed with the majority population. ${ }^{(8)}$ Today, Romas in Serbia have a settled lifestyle and any migration from villages to towns and from smaller to larger towns is primarily for economic reasons.

Owing to wars in the former Yugoslavia in the first half of the 1990s and armed conflicts in the southern part of Serbia in Kosovo at the end of the 1990s, a large number of refugees and internally displaced persons (IDPs) moved to central Serbia and Vojvodina, including a considerable number of Roma. ${ }^{(9)}$ Since 2003, people, primarily asylum seekers, whose right to reside in European Union member countries has expired, are also being sent back to Serbia, the largest percentage being Roma. ${ }^{(10)}$ There are no reliable data on where Roma IDPs and returnees settle. However, a number have settled in existing Roma settlements while the poorest among them have formed new informal settlements. ${ }^{(11)}$

In Serbia today, a number of national minorities, including Hungarians, Bosniaks, Slovaks, Bulgarians and Albanians, reside in towns and settlements with spatial characteristics and access to services that are no different to the average places where Serbs reside; and all towns in the country also contain small enclaves with deprived housing occupied by the general population. Only the Roma community faces social exclusion, discrimination and segregation in their daily lives in large numbers; most Roma settlements are clearly recognized as detached, impoverished entities.

\section{b. Roma population}

According to the 2002 census, Serbia has a population of around 7.5 million, including around 108,000 self-identified Roma. However, estimates by independent local and international researchers and RAs indicate that between 400,000 and 800,000 Roma live in Serbia, ${ }^{(12)}$ and similar data differences were also evident in earlier censuses. Roma often stated in census returns that they were members of the majority in Europe, particularly in the field of housing. See European Commission (2011), Communication to the European Parliament, the Council, the European Economic and Social Committee and the Committee of the Regions: An EU Framework for National Roma Integration Strategies up to 2020, COM(2011) 173 final, Brussels, page 2

2. Serbia adopted the following Law on the Protection of Rights and Freedoms of National Minorities (2002); Poverty Reduction Strategy (2003); Strategy for Improvement of the Status of Roma (2009); and Anti-discrimination Law (2009). Measures for Roma inclusion are also provided in national strategies in the field of education, health, social security, etc.

3. The Roma Decade is a political commitment by governments in central and southeastern Europe to improve the socioeconomic status of the Roma. See www. romadecade.org.

4. UN-Habitat (2006), Four Strategic Themes for the Housing Policy in Serbia, UN-Habitat, SIRP Programme, Belgrade, pages 32-35.

5. Vuksanović-Macura, Zlata and Vladimir Macura (2006), Stanovanje i Naselja Roma u Jugoistočnoj Evropi (Roma housing and settlements in southeastern Europe), OSCE/ ODIHR, Warsaw, 186 pages.

6. The term "slum" usually has derogatory connotations and can suggest that a settlement needs replacement or can legitimate the eviction of its residents. However, it is a difficult term to avoid for at least three reasons. First, some networks of neighbourhood organizations choose to identify themselves with a positive use of the term, partly to neutralize these negative connotations; one of the most successful is the National Slum Dwellers Federation in India. Second, the only global estimates for housing deficiencies, collected by the United Nations, are for what they term "slums". And third, in some nations, there are advantages for residents 
THE MAPPING AND ENUMERATION OF INFORMAL ROMA SETTLEMENTS

of informal settlements if their settlement is recognized officially as a "slum"; indeed, the residents may lobby to get their settlement classified as a "notified slum". Where the term is used in this journal, it refers to settlements characterized by at least some of the following features: a lack of formal recognition on the part of local government of the settlement and its residents; the absence of secure tenure for residents; inadequacies in provision for infrastructure and services; overcrowded and sub-standard dwellings; and location on land less than suitable for occupation. For a discussion of more precise ways to classify the range of housing sub-markets through which those with limited incomes buy, rent or build accommodation, see Environment and Urbanization Vol 1, No 2 available at http:// eau.sagepub.com/content/1/2 toc.

\section{Serbia attained full}

independence and international recognition in 1878 at the Berlin congress.

8. After the First World War, Serbia became part of the Kingdom of Yugoslavia. After World War II, the Socialist Federal Republic of Yugoslavia was formed, comprising six federal republics, one of which was Serbia, and two autonomous provinces, Vojvodina and Kosovo. After the disintegration of Yugoslavia, Serbia became an independent state again, while Kosovo has been under the administration of the United Nations since 1999.

9. Around 600,000 refugees moved to Serbia from former Yugoslav republics, and around 230,000 people left Kosovo and received the status of internally displaced persons (IDPS). Together, they made up around 8 per cent of Serbia's total population in 2000. There are a small number of Roma refugees, but there are an estimated 40,000-50,000 Roma IDPS. See Republic of Serbia (2011), National Strategy for Resolving Problems of Refugees and Internally Displaced Persons, population or local ethnic community. In academic literature, the difference between "ethnic origin" and "ethnic identity" is referred to as the "Roma's ethnic mimicry"(13) - by hiding their ethnic origin, Roma attempt to avoid discrimination and improve their social status. This is generally more evident among highly skilled workers or highly educated Roma.

Data from the 2002 population census indicate that Roma families have an average of 4.3 members, compared to three in the general population. ${ }^{(14)}$ Only 30 per cent of Roma finish elementary school and 0.3 per cent university. According to a 2007 living standards measurement study, their unemployment rate was 32 per cent compared to the general unemployment rate of 14 per cent. ${ }^{(15)}$ Roma are 7.5 times more at risk of poverty than the general population and their life expectancy is 48 years compared to a general average of 72 years.

\section{c. Roma settlements and housing}

The first and only enumeration of Roma settlements in Serbia was carried out in 2002 by the NGO Ethnicity Research Centre as part of the government's preparations to develop a national strategy to improve the Roma's position. ${ }^{(16)}$ They recorded 593 Roma settlements with a minimum size of 15 households, comprising 201,353 autochthonous Roma and 46,238 Roma IDPs, a total of 247,591. Although the research did not include Roma living in smaller settlements or those living with the majority population, it recorded around 140,000 more Roma than the population census from the same year. The research does not provide specific data on the ethnic structure of Roma settlements but generally refers to Roma as their sole inhabitants. Other research finds a small percentage of non-Roma in some otherwise Roma settlements. ${ }^{(17)}$

Almost half of the Roma settlements recorded in 2002 date back to before 1900, indicating their historical presence in the fabric of Serbian cities and towns. Only about 5 per cent of the settlements were formed after 1992. The majority, 53 per cent, had fewer than 200 inhabitants; around 30 per cent had between 200 and 500 inhabitants; and only 4 per cent had more than 2,000 inhabitants. Most Roma settlements are concentrated in two regions in Serbia, the Belgrade area and along the Sava River. The rest are scattered throughout the country (Figure 1). Around 53 per cent of settlements are in urban areas, while the rest are in the suburbs or rural areas.

Around 70 per cent of Roma settlements are considered to be informal. ${ }^{(18)}$ Half of these arose spontaneously on land not included in urban plans, while the other half were built counter to urban plans. The remaining 30 per cent were planned, although some encounter similar problems to the informal settlements. Households in around 75 per cent of the settlements face insecure land tenure ${ }^{(19)}$ and only a quarter of Roma households have built on their own land.

An analysis from 2005 indicated that Roma households have considerably poorer housing conditions than the general population. ${ }^{(20)}$ Around 37 per cent lack access to a water supply, compared to 8 per cent of households in the general population. Around 67 per cent of Roma households are not connected to a sewer, compared to 37 per cent of the majority population; and 11 per cent lack electricity, compared to 0.1 per cent. 


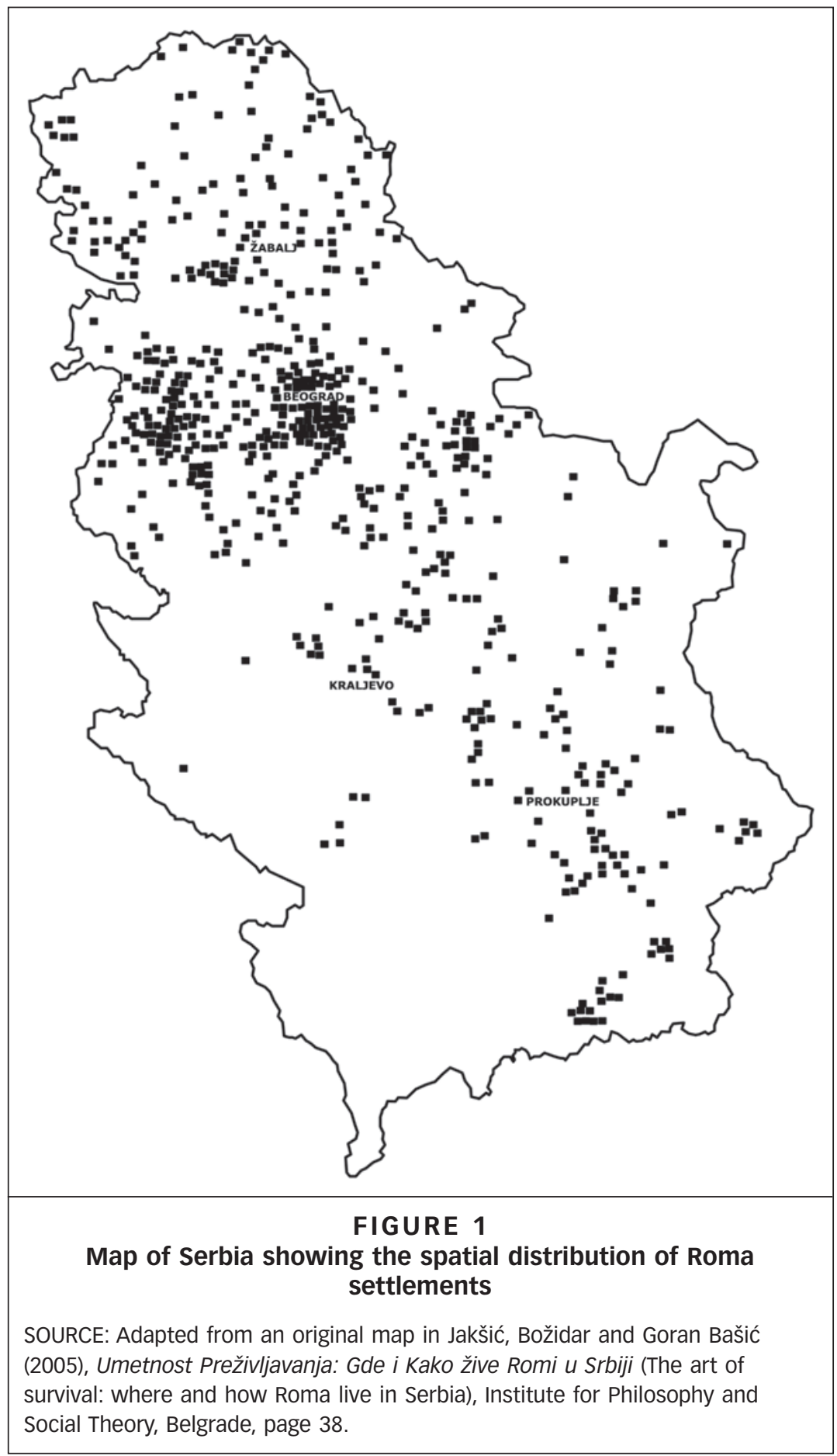

Government of the Republic of Serbia, Belgrade, 32 pages.

10. The number of returnees is estimated at between 50,000 and 100,000 , around 70 per cent of them Roma. See Republic of Serbia (2009), The Strategy of Returnees' Reintegration Based on the Readmission Agreement, Government of the Republic of Serbia, Belgrade, 31 pages.

11. UNHCR and the

Commissioner for Refugees of the Republic of Serbia (2011),

Assessment of the Needs of Internally Displaced Persons in Serbia, Commissioner for Refugees of the Republic of Serbia, Belgrade, 46 pages.

12. Considerable differences between statistical data and estimates exist in other European countries. See reference 1.

13. Mitrović, Aleksandra and Gradimir Zajić (1998), "Social position of the Roma in Serbia", in Centre for Anti-War Actions and Institute for Criminological and Sociological Research, The Roma in Serbia, Belgrade, pages 9-68.

14. Republic of Serbia (2010), Romi u Popisu: Probni Popis Domaćinstva i Stanova (Roma in the census: pilot census of households and dwellings), Statistical Office of the Republic of Serbia, Belgrade, 53 pages.

15. Vukmirović, Dragan and Rachel Smith Govoni (editors) (2008), Living Standard Measurement Study: Serbia 2002-2007, Statistical Office of the Republic of Serbia, Belgrade, 208 pages

16. Jakšić, Božidar and Goran Bašić (2005), Umetnost preživljavanja: gde i kako žive Romi u Srbiji (The art of survival: where and how Roma live in Serbia), Institute for Philosophy and Social Theory, Belgrade, 296 pages.

17. Eighty-one per cent of the 137 settlements recorded in the territory of Belgrade were inhabited exclusively by Roma; in the remaining 19 per cent, Roma lived together with the majority population or members of other ethnic groups. This research showed that only Roma live 
in slums. See Society for the Improvement of Local Roma Communities (SILRC) (2002), Review of Roma Settlements in Belgrade, only available in CD-ROM format.

18. In the past two decades, illegal construction in all forms and of different quality was the prevailing type of housing construction throughout Serbia. This was the result of transitional changes accompanied by economic and social problems and the great influx of refugees and IDPS. See UNECE (2009), Self-made Cities: In Search of Sustainable Solutions for Informal settlements in the UNECE Region, United Nations, New York and Geneva, 113 pages.

19. Data on ownership status is given based on cross-checking data from Jakšić and Bašić (2005) (see reference 16), SILRC (2002) (see reference 17) and 20 action plans in various municipalities. The percentages are therefore open to error.

20. Bodewig, Christian and Akshay Sethi (2005), Poverty, Social Exclusion and Ethnicity in Serbia and Montenegro: The Case of the Roma, World Bank, Belgrade, 63 pages.

21. See reference 5

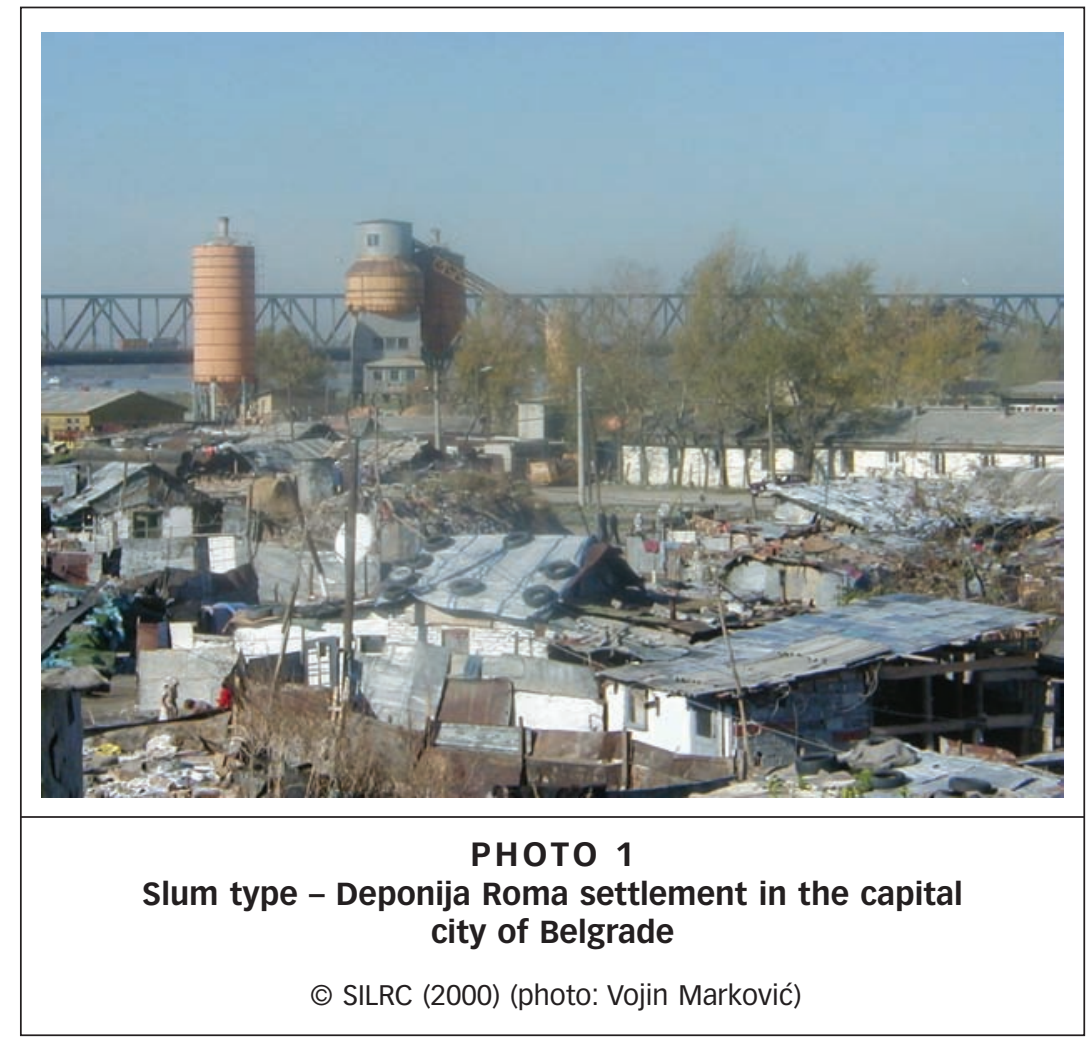

To support measures to improve conditions, it is important to distinguish between three kinds of settlement: ${ }^{(21)}$

"Slums", comprising 20 per cent of Roma settlements, are developed on illegally occupied land, often on environmentally hazardous sites (Photo 1). As a rule, they are built in larger cities by the most impoverished and vulnerable. They consist primarily of overcrowded shanties (or "barracks" as their residents often call them) without basic amenities or waste collection services. A house is often just one room measuring only 10 to 15 square metres. The open space next to the houses, hard to characterize as a yard, is usually shared among households. The settlements lack infrastructure, orderly networks of streets and public spaces. According to national and local strategic documents, most of these settlements should be removed.

Unserviced settlements arose primarily on land belonging to a variety of owners such as municipalities, the state and large enterprises, but often to the Roma themselves. They make up 69 per cent of Roma settlements (Photo 2). In most cases, these are old settlements with houses constructed of solid materials and ranging in size from 40 to 60 square metres, unskilfully built by the residents themselves, usually incrementally and generally unfinished. This type of settlement includes a small number of larger, better houses but also shanties like those in slums. Yards are clearly delineated and often very tidy. The settlements are partially supplied with water and electricity but most have no sewerage, and streets are narrow and insufficiently paved. Household garbage is not 


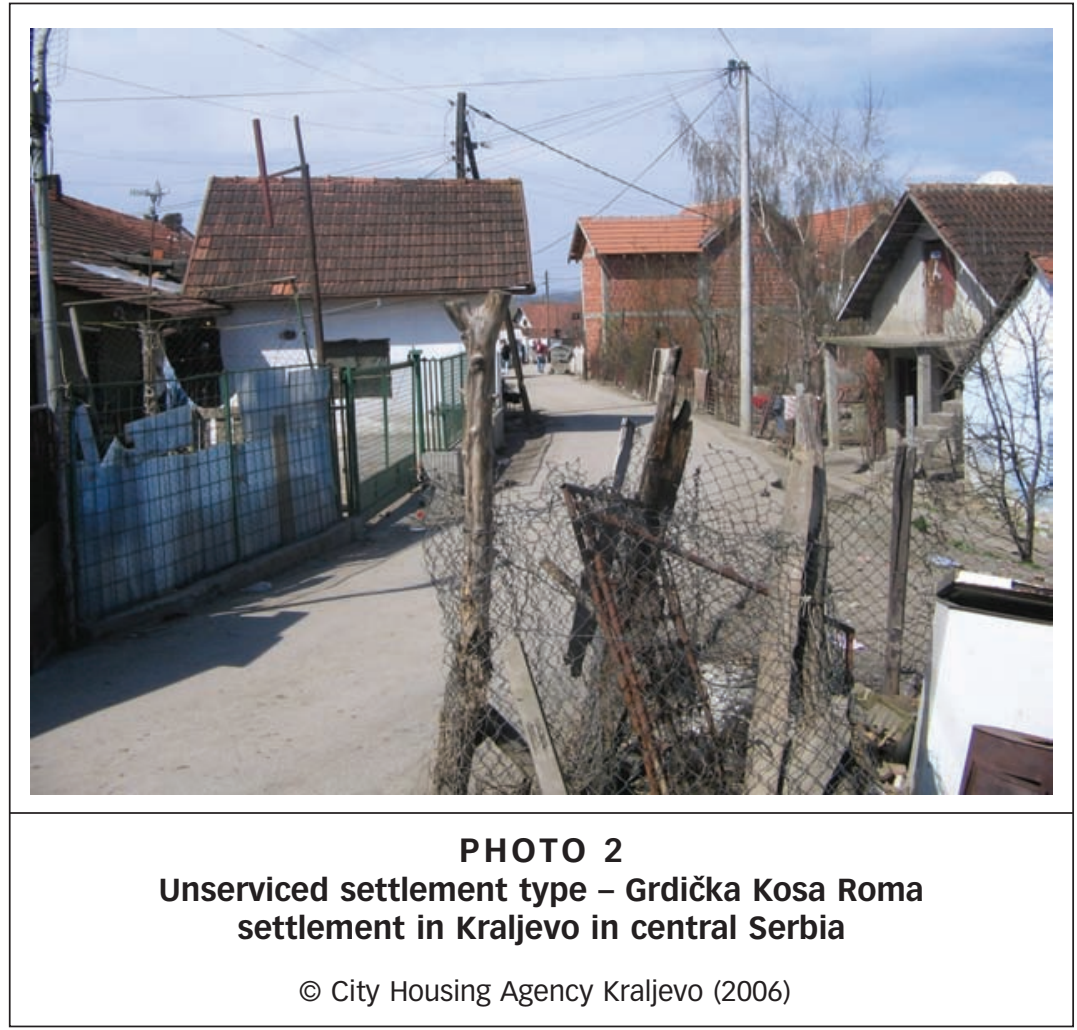

regularly collected. According to Serbia's strategic documents, most of these settlements should be legalized and upgraded.

Ordered settlements make up 11 per cent of the total and consist primarily of single family homes, often with an upper floor, measuring 150 to 200 square metres and sometimes even larger, built of solid, modern materials and equipped with all amenities (Photo 3). Generally, the residents own their land and houses, and most were built by people working abroad. The settlements have complete infrastructure and some social services depending on their size and position in the city, and tend to share the average characteristics of other parts of the city where they are located.

It is not easy to draw a clear line between these three types of settlement. Slums and unserviced settlements, especially, have some common traits - unplanned development, illegal sub-divisions of land, insecure tenure, inadequate access to sanitation and other infrastructure. ${ }^{(22)}$ The mapping and enumerations described in this paper were carried out in these two kinds of settlements.

\section{EXPERIENCE WITH MAPPING AND ENUMERATION}

In order to improve the living conditions of the inhabitants of informal Roma settlements, numerous issues must be resolved regarding land, housing, education, employment and health care, combined with a
22. UN-Habitat (2003), The challenge of Slums: Global Report on Human Settlements 2003, Earthscan, London and Sterling, pages 9-12. 
23. In Serbia, a comprehensive approach to improving the living conditions in Roma settlements was presented in the prize-winning proposal "Sustainable Renewal of the Eagle's Nest Gypsy Enclave in Belgrade" from the international competition of ideas "A Call for Sustainable Community Solutions" organized by the American Institute of Architects and the International Union of Architects in 1993 (authors Macura, V, A Mitrović, J Cvejić and Z Mujbegović). Based on this concept, the process of improving Eagle's Nest began and is still ongoing today. In 1997, this group of experts founded the NGO Society for the Improvement of Local Roma Communities (SILRC).

24. The experience in Serbia is close to the widely known method of participatory enumeration. See UN-Habitat (2010), Count Me In: Surveying for Tenure Security and Urban Land Management, UN-Habitat, Nairobi, 159 pages. Furthermore, in spite of differences in terms of population and spatial size of the settlements, certain similarities can be noted with examples in large slums in the world. See Karanja, Irene (2010), "An enumeration and mapping of informal settlements in Kisumu, Kenya, implemented by their inhabitants", Environment and Urbanization Vol 22, No 1, April, pages 217-239.

25. See reference 23.

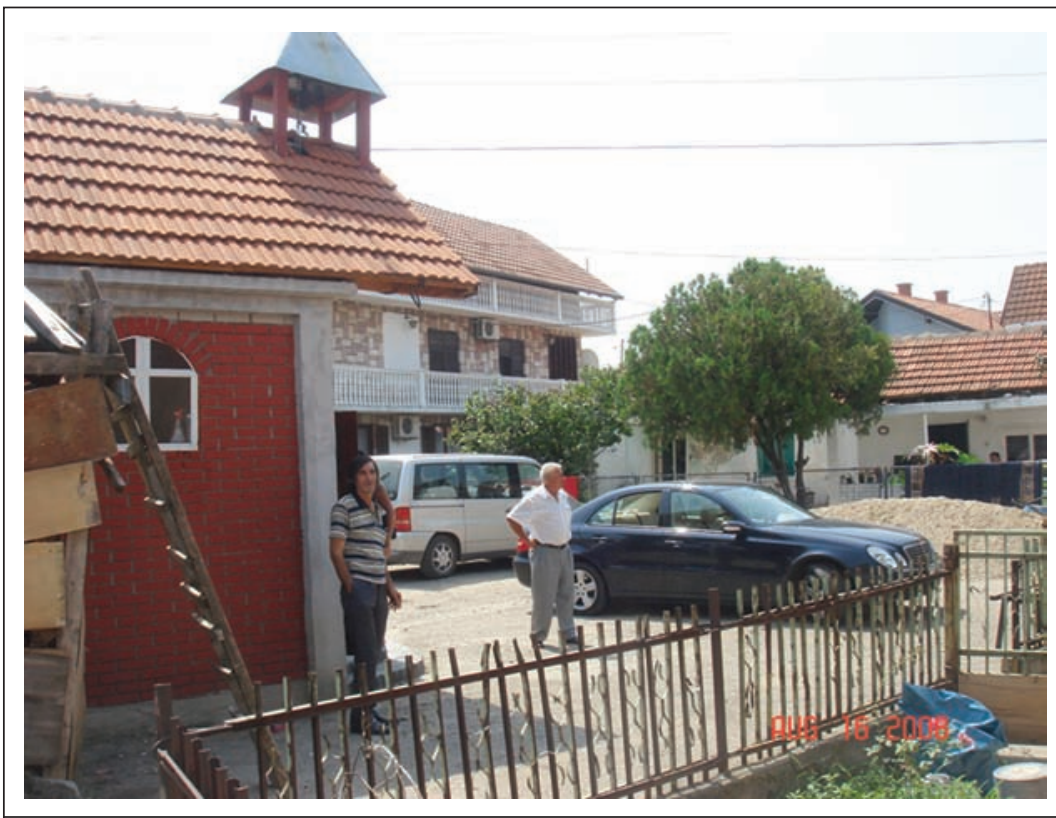

PHOTO 3

Ordered settlement type -Vasa Nikolić Roma settlement in Alekcinac municipality in southeastern Serbia

CSILRC (2008) (photo: Vladimir Macura)

campaign to counter discrimination, reduce poverty and encourage gender mainstreaming. ${ }^{(23)}$ In all these efforts, the process of mapping and enumeration is an important step both for planning and for implementing specific actions.

\section{a. Steps in mapping and enumeration}

The five examples of mapping and enumeration described in this paper were carried out over a period of 10 years, in different social and political contexts and in areas with varied development, and were implemented by organizations with different backgrounds. One of their most important common characteristics was the participation of the Roma themselves, diverse as that may be. ${ }^{(24)}$ The procedure, developed in the late 1990s by the NGO Society for the Improvement of Local Roma Communities (SILRC) ${ }^{(25)}$ from Belgrade, has been adapted by other Serbian organizations to correspond to their needs and context. This procedure consists of the following steps:

Gathering information. To increase the amount of information about a settlement for the project team and the community, data on the households and the settlement are gathered from various local sources, along with available maps. A considerable amount of information is also gathered through intensive fieldwork and conversations with the inhabitants. 
Designing a questionnaire to collect data and instructions on mapping and photographing. These instruments are adapted to specific project goals. Identification numbers link buildings on the ground to mapped houses and photographs. Usually, the questionnaire includes a section about the household and a section about the house and plot. Mapping instructions describe the spatial extent of the settlement with a legend adapted to the subject and mapping process. Photographing instructions give the angles of the shots, the number of photographs per house and how to code the photographs.

Training the enumeration teams. Training is the key to obtaining reliable results and is always adapted to the knowledge and previous experience of the enumerators. Training ensures a proper understanding of all the instruments and their proper application in the field.

Enumeration of households and houses. During enumeration, houses are first assigned a number that is linked directly to the questionnaire on the household, house and plot. Enumeration teams go from house to house and fill in the questionnaires based on the inhabitants' statements. Recognized representatives of the settlement accompany the enumerators, thus considerably reducing the potential for false statements. Leading members of the project team are also present to supervise the work of the enumerators. Enumeration usually lasts one or two days, but sometimes several weeks depending on the size of the settlement and the purpose of the enumeration and survey.

Mapping. All the houses, yards, outbuildings, streets, paths and existing infrastructure are mapped. The house numbers from the household questionnaires are entered on the maps. All types of available maps, digital orthophotos ${ }^{(26)}$ or Google Earth images are supplemented by measurements taken on the ground. Hand-drawn maps by the settlement inhabitants or NGO members together with the inhabitants enable a better understanding of the settlement's space and structure. A geodetic company is hired for precise cadastral-topographic maps.

Photographing. During mapping and enumeration the houses are photographed, with details of their construction and materials. One photograph always shows the identification number that is visibly written on the house, and characteristic entities of the settlement and all other buildings are also photographed. The photos allow a more detailed analysis when defining measures to repair and add on to houses and upgrade the settlement.

Data processing and use. Data on the households are entered into standard spreadsheet programmes and the maps are digitized to form a database. Data are considered to be valid when accepted by the local Roma community and local authorities, and are used to plan and implement specific actions.

In the past two decades, around 50 different initiatives have been launched in Serbia requiring the mapping and enumeration of individual settlements or a large number of Roma settlements at one time. ${ }^{(27)}$ Thus, 20 enumerations were undertaken of individual settlements, nine of them within the scope of different projects carried out by NGOs, 10 by local authorities and one for a student paper. Enumerations conducted by NGOs were accompanied by the compilation of a detailed map of the settlement and a socioeconomic survey of the households, while those conducted by local authorities included a general map of the settlement and a record of the number and quality of the houses. NGOs carried out
26. An orthophoto is an aerial photograph that has been geometrically adjusted for topographic relief, lens distortion and camera tilt so that the scale is uniform. The photo has the same lack of distortion as a map. See www.wikipedia.com for a full description.
27. No records exist on initiatives directed at improving the Roma's living conditions in Serbia. The analysis given here is based on data from various reports from local and international organizations. 
28. See Macura, Vladimir and Zlata Vuksanović (2003), Deponija to a Better Future, SILRC, Belgrade, 106 pages.

29. Belgrade has a population of around 1.3 million according to the 2002 census. See reference 17. these activities with the participation of the settlement residents, while the local authorities often relied on cooperation from Roma representatives who sometimes did not live in the settlement in question.

Recording larger numbers of Roma settlements at one time (30 cases) was primarily done by local authorities (18 cases) when developing local strategies or action plans to improve the situation of Roma living in their territory. There were several independent investigations (seven cases) and those carried out by NGOs (four cases) in conjunction with national or local authorities. While researchers and NGOs mapped Roma settlements with dots or denoted their borders on town maps, local authorities rarely did this. Even though these investigations were conducted through fieldwork, the settlement dwellers rarely took part. There are also cases where data were collected based on information available to employees in different municipal services, Roma representatives and RAs.

Of all the mappings and enumerations carried out, five cases will be presented here. These are: Deponija slum; a group of slums in New Belgrade; and three unserviced settlements, namely Grdička Kosa in Kraljevo in central Serbia, Ciganski Kraj in Žabalj in the northern part of the country and Mala Guba settlement in Prokuplje in southern Serbia. The criteria for their selection were:

- mapping and enumeration were undertaken in the settlement itself;

- $\quad$ settlement mapping and household enumeration were carried out side by side;

- settlement representatives and inhabitants participated in the mapping and enumeration process;

- the local Roma community accepted the results as accurate; and

- the local authorities accepted this material as authentic.

\section{b. Mapping and enumeration for socioeconomic empowerment - Deponija ${ }^{(28)}$}

Deponija settlement is situated on the banks of the Danube River around three kilometres from the centre of Belgrade, the capital of Serbia. ${ }^{(29)}$ It developed in the late 1960s on city land in the old industrial zone (Photo 1). The number of inhabitants doubled at the end of the 1990s with the arrival of Roma IDPs. In 2000, the settlement covered around six hectares and 856 people were living in 153 overcrowded shanties. Children and young people under the age of 16 comprised 47 per cent of the total number of inhabitants and only 20 of the 172 school-age children attended school. More than 90 per cent of the women were housewives and 70 per cent of them were illiterate. The main source of household income was from collecting secondary raw materials. Although most of the households have official house numbers, their position is very uncertain since Deponija is slated for demolition in urban plans, although no one knows when this will happen. That was the reason why a project to help these people was initiated.

Mapping and enumeration of the settlement took place in November 2000 as the initial phase of the Slum Upgrading Deponija project implemented by the NGO SILRC in cooperation with the RAs Romsko Srce (Roma Heart) and Bibija Roma Women's Centre. It was financed by the European Commission, UNICEF and the Netherlands Organization 


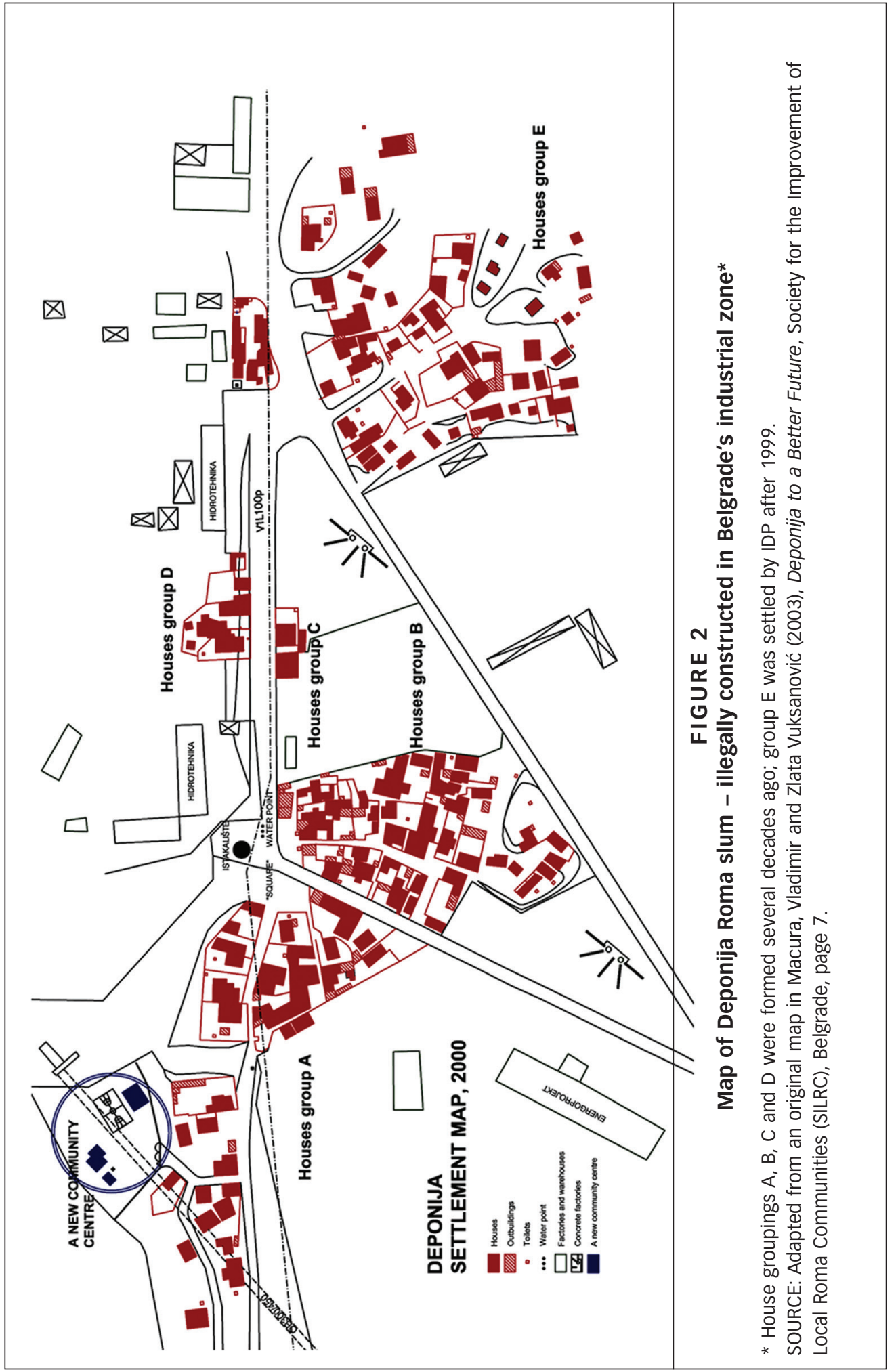


30. See New Belgrade Municipality (2006 unpublished), "Draft action plan on improving the position of those living in unsanitary settlements in the territory of New Belgrade", Mimeo, 36 pages; also information specially prepared for this paper by Živojin Mitrović, Director of Roma Association Romsko Srce.

31. Gazela slum had 173 households with 752 members in 2005 . When it was relocated in 2008, it had 220 households with 986 members. Belvil slum had 15 households with 59 members in 2005 and today's estimate is between 450 and 600 households for International Assistance (NOVIB OXFAM). Main project activities focused on socioeconomic empowerment of the community through the education of children and youth, work with women, vocational training and improving sanitation and hygiene in the settlement. Before the mapping and enumeration started, the project team became acquainted with the settlement and its inhabitants and informed them of the purpose of mapping and enumeration.

The basis for mapping the settlement was a cadastral map from 1984, which delineated roads and large cadastral parcels of the industrial zone but did not show a single Roma house. Five characteristic settlement sub-divisions were marked on this map. The mapping was carried out by teams consisting of an architect from the NGO SILRC and an RA member. Each team mapped one sub-division. The houses, outbuildings, yards, streets, paths and passages were measured using measuring tapes and 1:200 maps of the settlement areas were drawn by hand on the spot. In addition to the settlement's structure, garbage dumps that were to be removed were drawn on the maps along with vacant plots suitable for common and sanitation facilities. Based on the on-site drawings, a map of the whole settlement was compiled and digitized (Figure 2). At the same time, another group of teams collected data on household demographics (gender, age, income, etc.), which were entered into the database, processed in the Access programme and linked to the settlement map.

This database was used to plan activities and as the basis for a targeted survey of the needs of vulnerable women and children, which was conducted through structured interviews in homes in the following three months. In addition to collecting data needed to formulate tailored activities, the survey led to trust, respect and close relations between the project team members, children and parents. The project's greatest result was to include children in school. The newly formed RAs Romsko Srce and Bibija Roma Women's Centre also acquired skills in organizing, carrying out mapping and enumeration and other projects.

\section{c. Mapping and enumeration for local planning - New Belgrade ${ }^{(30)}$}

New Belgrade is one of 17 municipalities in the City of Belgrade, with a population of around 220,000 in 2002 . Built in the second half of the twentieth century as a predominantly residential zone, in the past two decades it has acquired large retail and business facilities as well as cultural and sports buildings and has become one of the most prestigious parts of the city. Nevertheless, large areas of land remained vacant while awaiting new investors. During the 1990s, small Roma slums started to crop up on these city "meadows". They were settled by IDPs, by returnees from Western Europe pursuant to "readmission agreements" and by migrant workers. Their housing situation was very uncertain, and after 2000, city authorities forced them off the land, which had been sold to various companies. These families then moved to the surrounding slums or to other unsold land, from where they were expelled once again. ${ }^{(31)}$

Appeals to respect human rights sent to the City of Belgrade and New Belgrade municipality by local NGOs and the international community temporarily halted the forced evictions. New Belgrade's action plan to respond to the new and complex situation required detailed data on the 
number and location of the settlements, the number of inhabitants and the socioeconomic situation of the households. Previous demolitions, however, had created great distrust among the slum dwellers towards any municipal action. In order to establish cooperation with the inhabitants, the municipality had to rely on the help of the RAs and NGOs. So the mapping and enumeration were entrusted to the RA Romsko Srce, with the technical assistance of the NGO SILRC and with municipality representatives taking part in the fieldwork. The mapping and enumeration of each settlement took place side by side over the course of one day, during July and August 2005.

Settlement mapping was based on a digital orthophoto from 2003. Although it was high resolution, some houses could not be distinguished from the surrounding piles of raw materials. Furthermore, new houses had appeared in the two years since the orthophoto had been taken and amendments had to be made in the field. An initial 1:200 working map, based on the orthophoto, was made for each settlement, to be used during recording in the field. Mapping and enumeration followed the same procedure for all the settlements. A municipal representative numbered the houses and photographed them. An architect from the NGO SILRC used a global positioning system (GPS) receiver to position new houses, update data and enter the house numbers on the map (Figure 3). Household enumeration was carried out by teams consisting of a representative of the RA and an inhabitant of the settlement. The enumeration survey collected data on the name of the settlement, the number, age and gender structure of the households, who had personal documents, the tenants' residence status, place of work and source of income, and whether children went to school and where. In this way, 15 Roma settlements were enumerated and mapped, including 582 households totalling 2,401 people. A final database was prepared using data from the surveys, the settlement maps and photos of the houses.

New Belgrade municipality used this data in 2005-2006 to elaborate a housing action plan that never became a reality. The problem of Roma settlements located on economically strategic land is still a politically sensitive topic in all larger cities in Serbia, since no clear implementation strategy accompanies the principle that they should be removed. ${ }^{(32)}$

\section{d. Mapping and enumeration for settlement upgrading - Grdička Kosa ${ }^{(33)}$}

Grdička Kosa is one of four Roma settlements in Kraljevo, a city in central Serbia with a population of around 63,000 (2002 census). Even though Grdička Kosa is only two kilometres from the city centre, it is on the periphery (Photo 2), separated from the city by disused railroad tracks. At the time of the survey, the settlement covered five hectares and consisted of 87 houses with 407 inhabitants. The first houses were built by five Roma families in 1904 on their own land. Most of the houses were built illegally in the mid-1980s, 37 on municipal land, 39 on land owned by Serbian Railways and a further six on their own land. The average house measured 32 square metres and typically consisted of two rooms, and 66 of the houses had no bathroom. The Roma population in the settlement is among the poorest in Kraljevo. The settlement has a settlement committee (SC) and two dozen inhabitants work actively in various RAs. The 2002
32. European Roma Rights Centre (2010), Standards Do Not apply: Inadequate Housing in Romani Communities, Budapest, pages 34-37.

33. Vuksanović-Macura, Zlata (2008), "Improvement and regularization of a Roma settlement in Kraljevo", in Ligia Ramirez et al. (editors), SIRP BOok: The Settlement and Integration of Refugees Programme in Serbia 20052008, UN-Habitat, Belgrade, pages 68-75. 


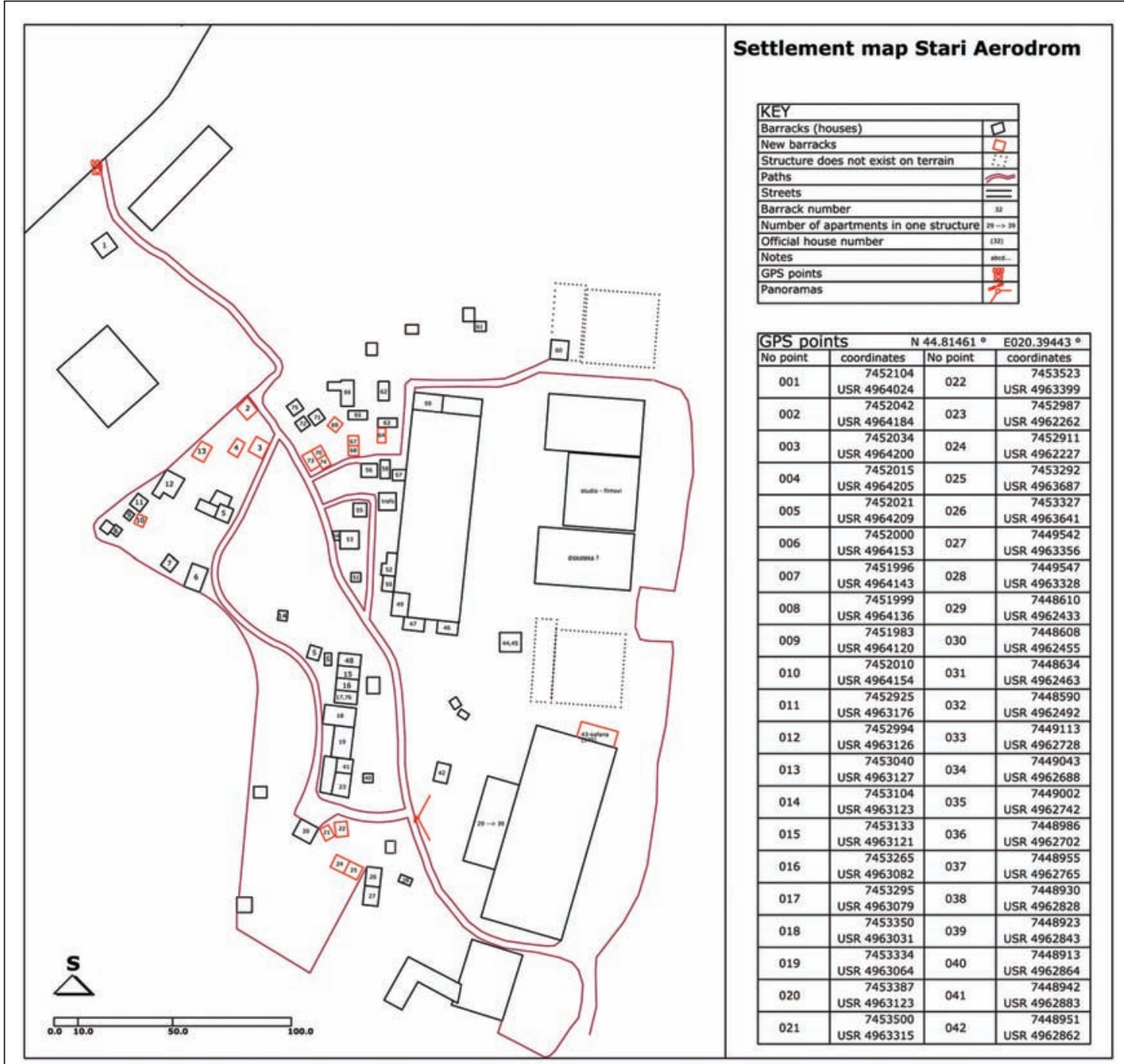

FIGURE 3

Sketch of the StariAerodrom Roma slum - one of 15 illegally built Roma settlements in New Belgrade mapped in 2005*

* The structures and paths were drawn from an orthophoto, with additions from the field using a GPS receiver. SOURCE: Roma Association Romsko Srce (2005).

Kraljevo Master Urban Plan marked the settlement as a residential zone for the first time, the first step in its legalization. Municipal authorities gradually organized the settlement through the partial introduction of water, sewer and power lines, primarily through ad hoc actions during campaigns for local elections.

The Grdička Kosa SC enumerated the households in cooperation with the City Housing Agency (CHA) within the scope of the Upgrading and Inclusion project that was widely supported both financially and 
technically by the United Nations Human Settlements Programme in Serbia (UN-Habitat). ${ }^{(34)}$ The project's main activities focused on developing an urban plan, on further construction of the sewer and power networks and on improving housing conditions for the most vulnerable families. Mapping and enumeration were carried out in April and May 2007.

Construction of the infrastructure required an accurate map of the settlement, so a geodetic company was hired to make a 1:500 topographic map of the settlement (Figure 4) using the theodolite survey method. In addition to the mandatory components required by law, the map included: cadastral parcels; plots of land based on inhabitants' statements; houses; outbuildings; buildings under construction; paths and approaches to houses; water and sewer manholes; and power lines. This map was used to produce contractors' plans to link into the sewer and power networks and to put in street lights, all of which was completed.

Enumeration was carried out by teams of two people from SC Grdička Kosa, and the leader of the enumeration was a Roma from the settlement, chosen by the inhabitants. During enumeration, employees from the CHA and UN-Habitat offered help to the enumerators. Enumeration provided information on the number of households and their structure and income; also data on housing conditions, including the quality of the houses, their size and structure and existing public utilities. The CHA created a database using information from the household enumeration and a map of the settlement. This database, along with additional consultations with the settlement inhabitants, allowed the SC to choose the 20 most vulnerable families whose housing conditions were to be upgraded. After talking to the families, the initial idea of adding a bathroom to their houses had to be reconsidered. Some asked to have another room built and others wanted to resolve problems with a leaky roof and dampness rather than build a bathroom. Thus, housing conditions were upgraded based on the needs of each household.

Working closely with the Roma community to upgrade the settlement was a completely new experience for the CHA and the local authorities and spurred them into considering the possibility of upgrading other Roma settlements in Kraljevo. Another Roma settlement thus received a water supply network and street lights. In 2008, measures to upgrade Roma settlements were included in the local housing strategy, thereby creating the possibility of their greater institutional care.

\section{e. Mapping and enumeration for assisted self-construction - Ciganski Kraj ${ }^{(35)}$}

The Ciganski Kraj (Gypsy neighbourhood) Roma settlement is located in the municipality of Zabalj in the province of Vojvodina in the northern part of Serbia. Žabalj municipality, with around 28,000 inhabitants in 2002 , consists of four semi-urban settlements. Ciganski Kraj, located on the outskirts of one of these, has been there for more than 60 years and today has 326 inhabitants living in 76 houses, built illegally by the Roma on municipal land. The houses are modest, single-storey and consist of one to three rooms. They are solidly constructed but 95 per cent have defects. The settlement has a water supply system and paved streets but no sewer connection or wastewater outlet. Only 10 houses have bathrooms. Household income derives primarily from seasonal work on the surrounding farms.
34. UN-Habitat brought new techniques, greater financial resources and instruments to include local authorities in projects to improve Roma settlements in Serbia.
35. See Bu, Robert and Daniel Wyss (2010), Social Inclusion and Improvement of Housing in Roma Settlements in the Autonomous Province of Vojvodina, Republic of Serbia, EHO, Novi Sad, 24 pages; also information specially prepared for this paper by Robert Bu, coordinator of EHO RRC housing projects. 


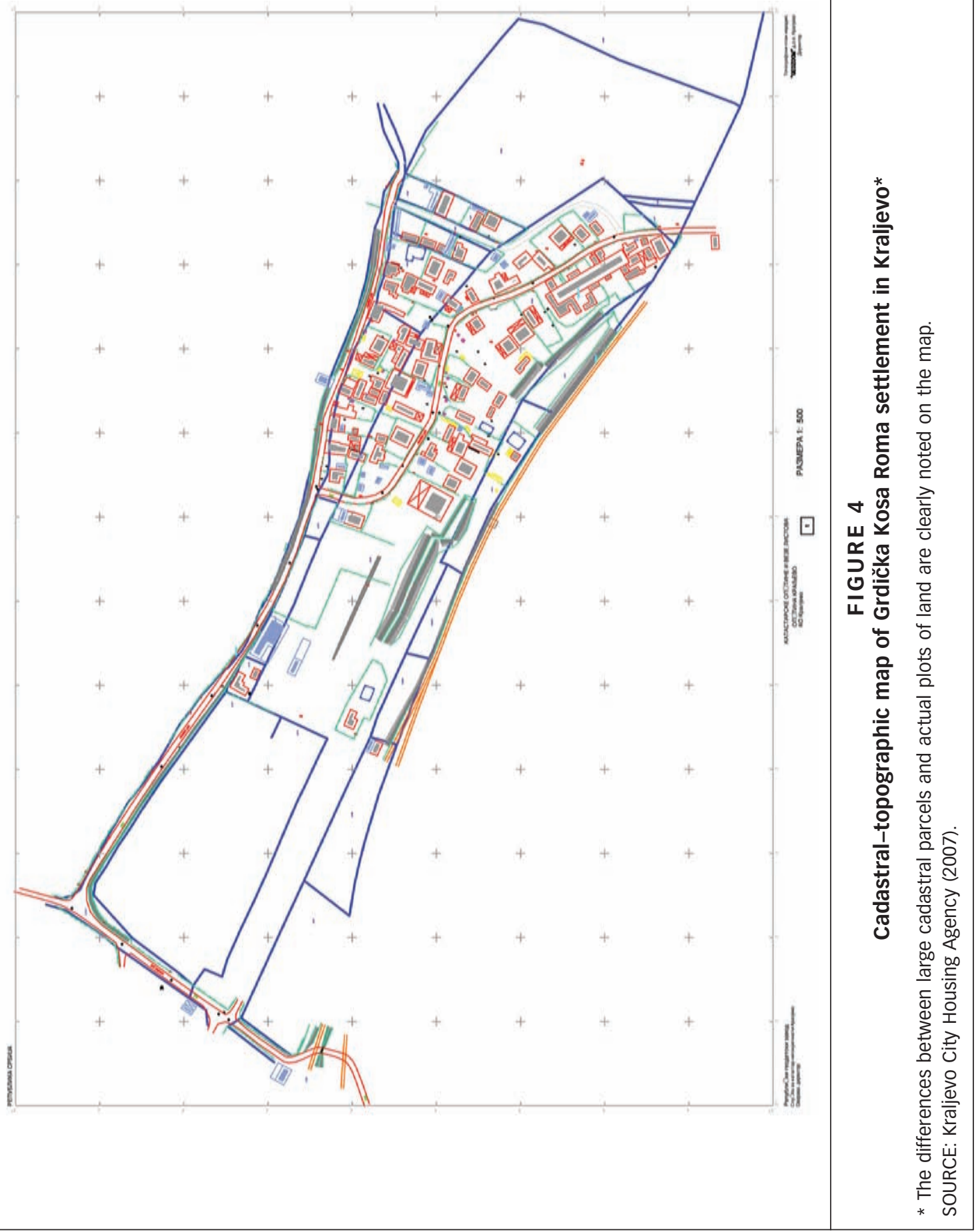


Mapping and enumeration of the settlement were carried out between January and March 2009 within the scope of the Housing Improvement project implemented by the Roma Resource Centre of the Ecumenical Humanitarian Organization (EHO RRC), in conjunction with the municipality. The project was financed by Swiss Interchurch Aid, the Swiss Agency for Development and Cooperation and Žabalj municipality. The project's goal was to improve housing conditions by reconstructing houses and building bathrooms and septic tanks, using the assisted self-construction model. Before the beginning of mapping and enumeration, EHO RRC organized meetings with the settlement inhabitants to form an SC that represented the entire settlement. A project forum, made up of SC members, municipality and public utility representatives and members of EHO RRC, explored the most favourable models to resolve housing problems.

A survey, carried out by two teams of enumerators from EHO RRC, recorded the households' needs with regard to expansion and connection to public utilities, their financial capacity and their ability and readiness to take part in self-construction. Household members were also questioned on the vocational training they would like, and how the skills they acquired could be used to repair their own houses, help their neighbours or be used in jobs outside the settlement. Technical documentation was elaborated for every house based on established needs. Google Earth images were used to make a map of the settlement showing the houses and their numbers.

Information about the households and their houses was entered into the database and online files were linked with the Google Earth images and the photo album (Figure 5). The database was used to plan individual repairs and additions to houses, determine the types of professional assistance needed and to monitor project implementation.

\section{f. Mapping and enumeration to legalize the settlement and houses - Mala Guba( ${ }^{(36)}$}

The Roma settlement of Mala Guba is located on the outskirts of the town of Prokuplje, population 27,000, in the southern part of Serbia, one of the poorest areas in the country. The settlement originated in the 1960s on the alluvium of a stream at its confluence with a larger river, but most of the settlement was built during the 1990s. Today it covers 3.1 hectares and comprises 47 houses and 247 inhabitants. Almost all of the houses are made of modern materials but they are unfinished. Twelve houses were built on municipal land and the rest are on land that the Roma bought but did not enter in the land registry. All the houses were built without building permits. In 2009, more than one-third of the households took advantage of the opportunity to apply for legalization of their houses, ${ }^{(37)}$ but owing to the unresolved problems of ownership and the failure of houses to meet building regulation standards, their legalization is still pending. Public areas and streets are poorly maintained and public utilities are only partially installed. The greatest problems are the increasingly frequent flooding that jeopardizes the alluvial part of the settlement, the lack of a sewer system and the informal water supply system throughout the settlement.

In mid-2010, the municipality adopted local action plans to improve the Roma's housing conditions based on national regulations ${ }^{(38)}$ and
36. Information specially prepared for this paper by Roma Association Društvo Rom Prokuplje and NGO SILRC.

37. The Law on Planning and Construction (2009/2011) stipulates the terms and regulates the process for subsequently obtaining a building permit for a building that was constructed without one.

38. One of the most important is Guidelines for the Legalization of Informal Roma Settlements. 


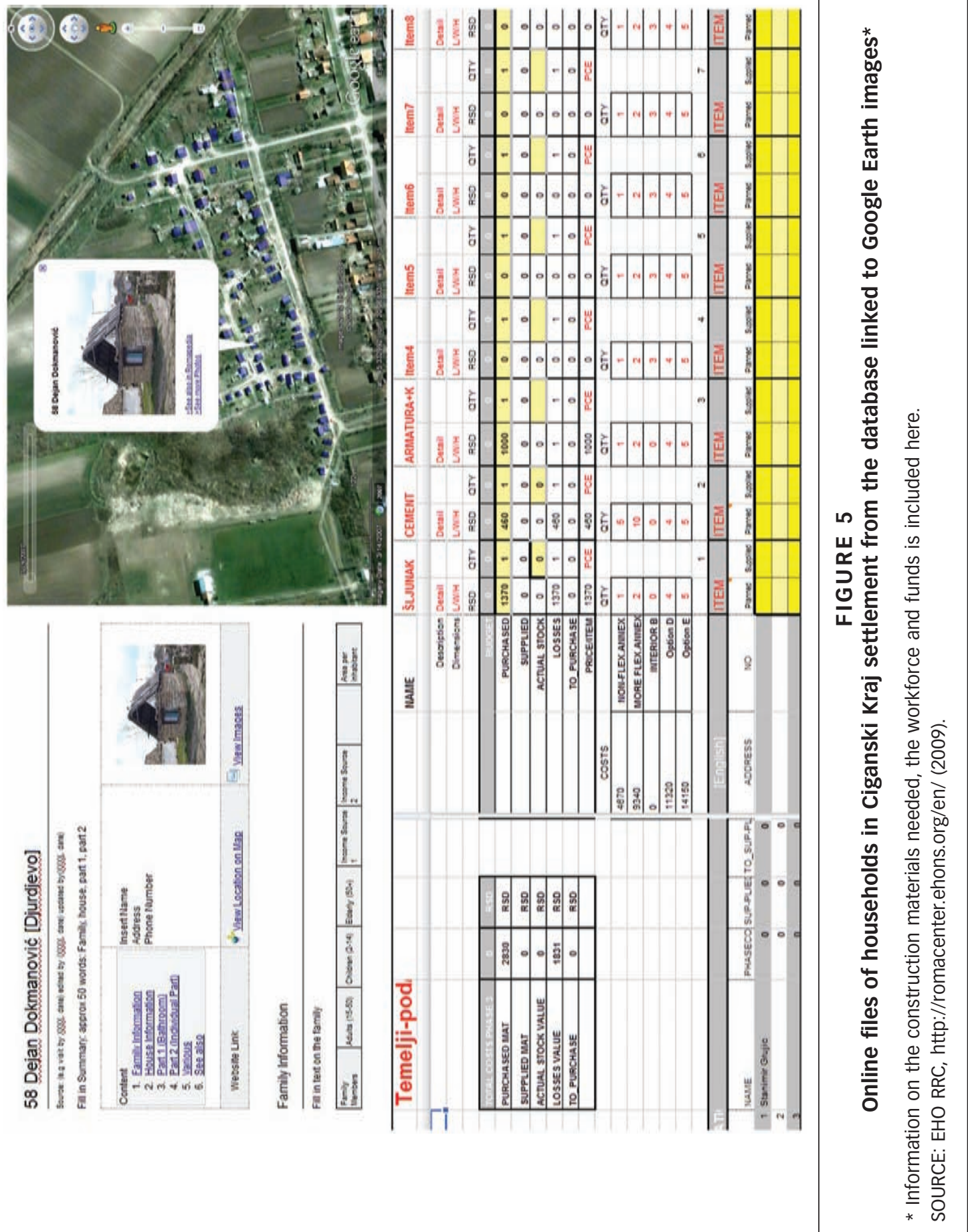




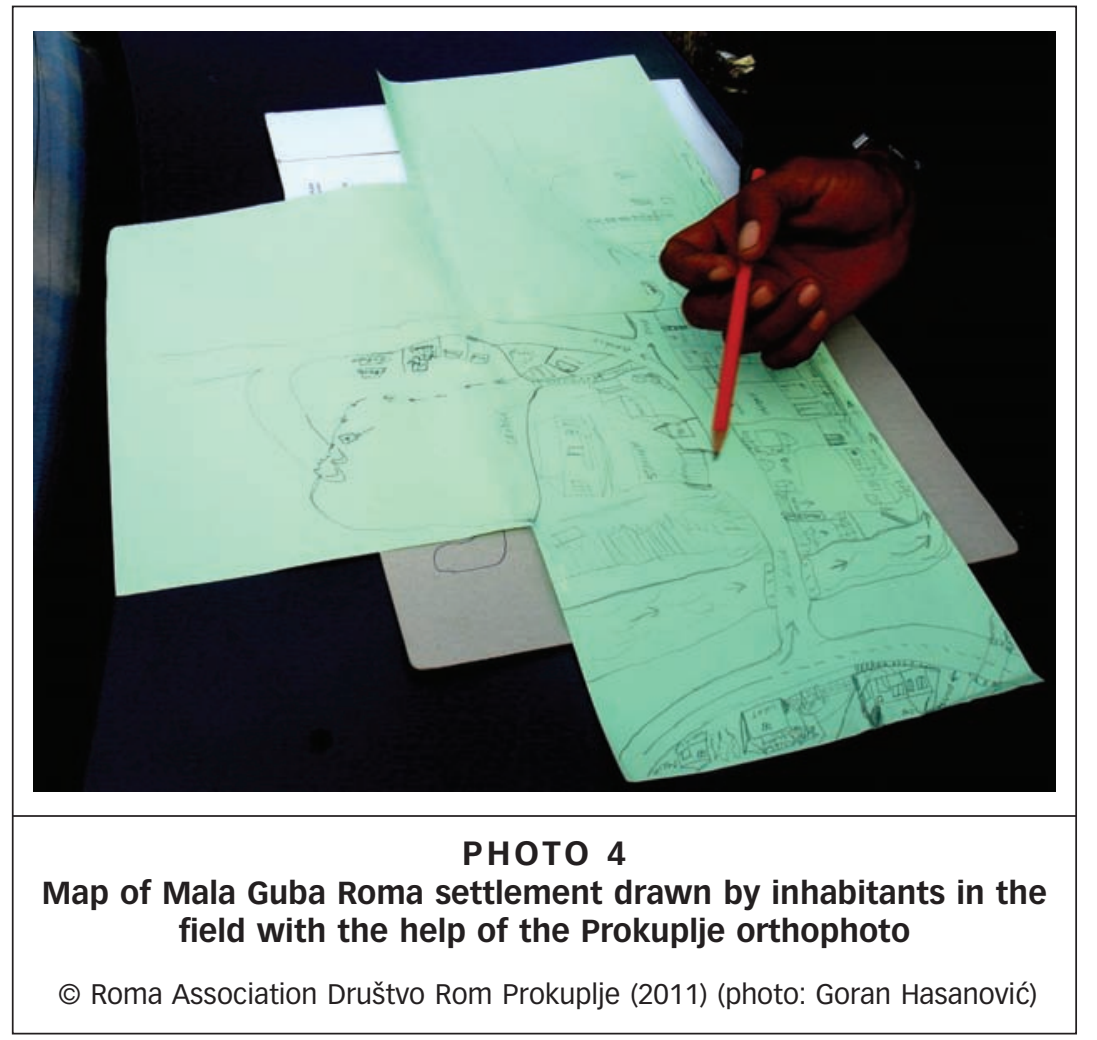

international documents. This encouraged the Društvo Roma Prokuplje RA to launch a project in early 2011 to legalize and upgrade the informal Roma settlement of Mala Guba. The project is being carried out with the close involvement of local authorities and public enterprises and with the professional assistance of the NGO SILRC from Belgrade. The ultimate goal is to legalize municipal services, houses and other settlement structures. This requires an urban plan, land readjustment and upgrading, the management of municipal services and the repair and upgrading of houses. The project is in its initial phase and the settlement and its development prospects are being assessed.

Enumeration and mapping were carried out in June 2011. The RA and the inhabitants drew a map of the settlement including streets, houses and yards (Photo 4). An enumeration questionnaire was put together by the project team based on a template from SILRC. Four teams of two people each, one from the RA and one from the settlement, carried out the enumeration, assisted and supervised by project team leaders. In addition, one person put numbers on the houses and another photographed them.

In parallel with this process, data were gathered about previous flooding of the site and steps were taken to compile topographiccadastral maps of the settlement. The inhabitants elected an SC, which visited all the households and recorded needed improvements, including expanding existing houses, finishing roofing and covers, 
treating dampness, fixing sewer connections and electricity, providing insulation and façade work and constructing new houses to replace those that cannot be repaired. This data will be used to define an inexpensive construction model based on self-construction using recycled materials and also to define various financing models. In addition, municipal services are considering options to cede the land to the families that have already built houses and are taking steps to draw up an urban plan. The RA and the municipality are working together on fundraising and including other stakeholders.

\section{FINAL REFLECTIONS}

Although most Roma settlements in Serbia can be described as impoverished and informal, they differ from each other in numerous ways related to the development level of the region, the local authorities' attitude towards the settlement and the relationship between the Roma community and the majority population. In some settlements, the lack of infrastructure is the basic problem; for others it is sub-standard housing; for yet others it is the constant threat of demolition because of illegal construction on municipal land. These problems have a direct impact on upgrading goals. The mapping and enumeration of informal Roma settlements always starts from a specific project and its goal. This provides a tailored approach, since every settlement requires individual treatment.

Different teams set up by local RAs and NGOs to implement upgrading projects in different municipalities have related approaches, in principle. First, there is always noticeable cooperation with formal or informal groups from the settlements and SCs, and in some phases of work with the entire settlement population. Second, mapping, enumerating and photographing are most often done side by side as integrated activities to establish facts and form an integrated database. Third, further data analysis leads to conclusions by the RA, SC and project team, who recommend specific actions to improve the situation. These actions can be highly diverse, including, for example, assisting children to enrol in school and finish school, providing support to households to increase their income, or improving housing conditions.

The databases compiled by NGOs and RAs during mapping and enumeration have limited scope but they are very important in the initial phases of a project. The low cost of compiling and analyzing these databases makes them suitable for NGOs and RAs. Poor Roma settlements can use them for lobbying, fundraising and to connect with local authorities; also for specific work in the field. There have also been cases where local authorities have accepted these databases to improve an extremely unsanitary situation, by introducing minimal public infrastructure in a settlement. On the other hand, should a settlement upgrading initiative begin formal administrative procedures - producing an urban plan, initiating court proceedings to transfer ownership, legalizing illegally constructed houses and municipal utility systems, entry in the land registry - then data collected through mapping and enumeration are insufficient because procedures based on the law require official documentation, similar to other city areas. 
The mapping and enumerations carried out by NGOs and RAs have a broader social impact. They show that it is possible, with motivated and well-trained enumerators and well-informed inhabitants, to collect data sensitive to cultural diversity. As mentioned previously, in 2002 the national government carried out an enumeration of Roma settlements in Serbia. But there was no increase in the real awareness of their problems at the higher political levels until detailed data on individual cases were reproduced, showing not only the settlements' poverty but their potential as well. Although some Roma settlements have existed for decades, and some for more than two centuries, local authorities only started finding out about them when they were presented with data and analyses resulting from the mapping and enumerations. In the past decade, the systematic approach required by mapping and enumerations has also helped RAs to develop their organizational and administrative capacities. Some have established a more efficient internal organization, have broken free to work independently on fundraising, have taken a braver approach to problems and are finding innovative solutions and making a better case for themselves before local authorities.

Participation by Roma living in the enumerated settlements has facilitated a better understanding of their household and community needs, priorities, aspirations and potential. It has enabled them to concretize and articulate their problems and helped them formulate proper measures to improve their living conditions within the scope of local action plans and strategies. Nevertheless, additional work is needed to develop the instruments and capacities of representatives and of national and local authorities, in order to draw official attention to the Roma's needs, aspirations and priorities when elaborating relevant strategic documents and programmes that concern the Roma community.

The process of upgrading informal Roma settlements might take years or decades, but regardless of the duration, the effects of the initial project development phase remain. They are reflected above all in improved relations between the general population and the Roma community, and by the inclusion of Roma settlements and their inhabitants in formal and official systems. All of the projects that were or are being successfully carried out in Serbia have these features: good understanding between local authorities and the Roma; the inclusion of other stakeholders; decreasing discrimination; increasing tolerance; and better social inclusion of the Roma population.

The procedures used in Serbia today by NGOs and RAs to map and enumerate are limited by the professional capacity of the teams, available funds and the quality and scope of existing maps, records and other input documents. It is a fact that the procedures presented here require further improvement. One objective of future methodological research should be to further standardize these procedures. There are at least three reasons for this: first, greater data reliability about specific settlements; second, increased trust by local and higher authorities in the data they receive; and third, but certainly not last, the initiation of debates on the need to amend the existing system of national regulations, standards and procedures to make them more compatible with the realities of Roma settlements' inhabitants and the local authorities. No one in Serbia is currently working on this issue. 


\section{REFERENCES}

Bodewig, Christian and Akshay Sethi (2005), Poverty, Social Exclusion and Ethnicity in Serbia and Montenegro: The Case of the Roma, World Bank, Belgrade, 63 pages.

$\mathrm{Bu}$, Robert and Daniel Wyss (2010), Social Inclusion and Improvement of Housing in Roma Settlements in the Autonomous Province of Vojvodina, Republic of Serbia, EHO, Novi Sad, 24 pages.

Environment and Urbanization Vol 1, No 2 available at http://eau.sagepub.com/content/1/2.toc.

European Commission (2011), Communication to the European Parliament, the Council, the European Economic and Social Committee and the Committee of the Regions: An EU Framework for National Roma Integration Strategies up to 2020, COM(2011) 173 final, Brussels, 18 pages.

European Roma Rights Centre (2010), Standards Do Not Apply: Inadequate Housing in Romani Communities, Budapest, 75 pages.

http://romacenter.ehons.org.en.

Jakšić, Božidar and Goran Bašić (2005), Umetnost preživljavanja: gde i kako žive Romi u Srbiji (The art of survival: where and how Roma live in Serbia), Institute for Philosophy and Social Theory, Belgrade, 296 pages.

Karanja, Irene (2010), "An enumeration and mapping of informal settlements in Kisumu, Kenya, implemented by their inhabitants", Environment and Urbanization Vol 22, No 1, April, pages 217-239.

Macura, Vladimir and Zlata Vuksanović (2003), Deponija to a Better Future, SILRC, Belgrade, 106 pages.

Mitrović, Aleksandra and Gradimir Zajić (1998), "Social position of the Roma in Serbia", in Centre for Anti-War Actions and Institute for Criminological and Sociological Research, The Roma in Serbia, Belgrade, pages 9-68.

New Belgrade Municipality (2006 unpublished), "Draft action plan on improving the position of those living in unsanitary settlements in the territory of New Belgrade", Mimeo, 36 pages.

Republic of Serbia (2009), The Strategy of Returnees' Reintegration Based on the Readmission Agreement, Government of the Republic of Serbia, Belgrade, 31 pages.

Republic of Serbia (2010), Romi u Popisu: Probni Popis
Domaćinstva i Stanova (Roma in the census: pilot census of households and dwellings), Statistical Office of the Republic of Serbia, Belgrade, 53 pages.

Republic of Serbia (2011), National Strategy for Resolving Problems of Refugees and Internally Displaced Persons, Government of the Republic of Serbia, Belgrade, 32 pages.

Society for the Improvement of Local Roma Communities (SILRC) (2002), Review of Roma Settlements in Belgrade, only available in CD-ROM format.

UNECE (2009), Self-made Cities: In Search of Sustainable Solutions for Informal Settlements in the UNECE Region, United Nations, New York and Geneva, 113 pages.

UN-Habitat (2003), The Challenge of Slums: Global Report on Human Settlements 2003, Earthscan, London and Sterling, 310 pages.

UN-Habitat (2006), Four Strategic Themes for the Housing Policy in Serbia, UN-Habitat, SIRP Programme, Belgrade, 56 pages.

UN-Habitat (2010), Count Me In: Surveying for Tenure Security and Urban Land Management, UN-Habitat, Nairobi, 159 pages.

UNHCR and the Commissioner for Refugees of the Republic of Serbia (2011), Assessment of the Needs of Internally Displaced Persons in Serbia, Commissioner for Refugees of the Republic of Serbia, Belgrade, 46 pages.

Vukmirović, Dragan and Rachel Smith Govoni (editors) (2008), Living Standard Measurement Study: Serbia 2002-2007, Statistical Office of the Republic of Serbia, Belgrade, 208 pages.

Vuksanović-Macura, Zlata (2008), "Improvement and regularization of a Roma settlement in Kraljevo", in Ligia Ramirez et al. (editors), SIRP Book: The Settlement and Integration of Refugees Programme in Serbia 2005-2008, UN-Habitat, Belgrade, pages 68-75.

Vuksanović-Macura, Zlata and Vladimir Macura (2006), Stanovanje $i$ Naselja Roma u Jugoistočnoj Evropi (Roma housing and settlements in southeastern Europe), OSCE/ODIHR, Warsaw, 186 pages.

www.romadecade.org.

www.wikipedia.com. 